\title{
The Resurrection of Jesus: do extra-canonical sources change the landscape?
}

F P Viljoen \& A E Buglass

(North-west University - Potchefstroom campus)

\section{ABSTRACT}

\section{The Resurrection of Jesus: do extra-canonical sources change the landscape?}

The resurrection of Jesus is assumed by the New Testament to be a historical event. Some scholars argue, however, that there was no empty tomb, but that the New Testament accounts are midrashic or mythological stories about Jesus. In this article extra-canonical writings are investigated to find out what light it may throw on intracanonical tradition. Many extra-canonical texts seemingly have no knowledge of the passion and resurrection, and such traditions may be earlier than the intra-canonical traditions. Was the resurrection a later invention? Are intra-canonical texts developments of extracanonical tradition, or vice versa? This article demonstrates that extra-canonical texts do not materially alter the landscape of enquiry.

\section{THE QUESTION OF SOURCES}

Jesus' resurrection is central to New Testament tradition, both as historical event and as theological metaphor. There are two main strands of early tradition: appearance stories and stories about the empty tomb. The earliest witness is Paul, who uses the appearancetraditions and makes nothing of the tomb apart from a passing reference (1 Cor. 15:4). Empty tomb stories enter New Testament writings later through Mark and develop through the Gospel traditions. The question is whether the New Testament is the only or best source of material about the resurrection.

Some early Christian writings were chronologically close to later canonical writings. The First Letter of Clement dates from c96 (Staniforth 1987:20), and the Didache could have begun late in the first century (Kleist 1948:5). The Gospel of Thomas was composed before the Oxyrhynchus papyri (c 140), but after 70 (Theissen \& Merz 1998:38).

Since most patristic writings are later than canonical writings, dependence has been assumed (Theissen \& Merz 1998:40). 
However, some may have preserved earlier forms of tradition than canonical texts (Staniforth 1987:189), and according to some scholars are possibly more reliable. Crossan "does not count any of the canonical Gospels as primary sources, preferring the earliest stratum of the Gospel of Thomas, the Egerton Gospel, the Gospel of the Hebrews, the Logia source and a 'Cross Gospel' reconstructed from the Gospel of Peter" (Theissen \& Merz 1998:11). Crossan's stratification of sources (Crossan 1992.427ff) is discussed below (2.1); he argues his case further in engaging with some of his critics (Crossan 1998:114ff).

This article will explore the nature and relationship of the sources of the Jesus tradition, and seek to clarify the implications of their relationship for the transmission of the tradition.

\section{CATALOGUING SOURCES ABOUT JESUS}

There are Christian and non-Christian sources about Jesus (Theissen \& Merz 1998:17ff). These sources indicate the awareness of Jesus tradition.

\subsection{Cataloguing the sources}

Theissen \& Merz groups Christian sources about Jesus in four groups ${ }^{1}$.

- Synoptic sources: the Logia source (Q), and the Gospels of Mark, Matthew and Luke;

- Gospels close to Gnosticism: the Gospels of John and Thomas (see 3.2.1 below);

- Jewish-Christian Gospels: the Gospels of the Nazarenes, the Ebionites, and the Hebrews; the Gospels of the Ebionites and the Hebrews are known only from patristic references (cf. Kloppenborg 1990:77);

- Gospel fragments with Synoptic and Johannine elements: Pap. Egerton 2, the Gospel of Peter, the Secret Gospel of Mark, and Papyrus Oxyrhynchus 840.

1 They don't include Paul as a principal source of Jesus tradition, although Paul incidentally includes information about Jesus in his letters. Paul did not use the letters to pass on the Jesus tradition, because he had already done it in his missions (cf. Dunn 1998:189). 
The Jewish-Christian Gospels all depend on canonical Gospel traditions. The Oxyrhynchus papyrus may be related to synoptic material, but is too fragmentary for firm conclusions (Theissen \& Merz 1998:51).

The non-Christian sources are (Theissen \& Merz 1998:61ff) Josephus' "Testimonium Flavianum", rabbinic comments about Jesus, the Stoic Mara bar Sarapion, and Roman comments on the founder of the Christian sect. They help to confirm Jesus' existence (Theissen \& Merz 1998.85). The only reference to the resurrection is in the Testimonium Flavianum, which is either a Christian interpolation, or a comment on what Jesus' followers believed (Theissen \& Merz 1998:65ff).

Crossan attempts to stratify sources chronologically (Crossan 1992.427ff):

- First Stratum [30-60 CE] 1 Thessalonians, Galatians, 1 Corinthians, Romans, first layer of the Gospel of Thomas, Egerton Gospel, Pap. Vienna Greek 2325, Pap. Oxy.1224, Gospel of the Hebrews, Sayings Gospel Q, Miracles Collection, Apocalyptic Scenario, Cross Gospel.

- Second Stratum [60-80 CE] Gospel of the Egyptians, Secret Mark, Gospel of Mark, Pap. Oxy. 840, second layer of the Gospel of Thomas, Dialogue Collection, Signs Gospel, Colossians.

- Third Stratum [80-120 CE] Gospel of Matthew, Gospel of Luke, Revelation, 1 Clement, Epistle of Barnabas, Didache 1:1-3a; 2:216:2, Shepherd of Hermas, James, first edition of the Gospel of John, Letters of Ignatius, 1 Peter, Letter of Polycarp to the Philippians 13-14, 1 John.

- Fourth Stratum [120-150 CE] Second version of the Gospel of John, Acts, Apocryphon of James, 1 Timothy, 2 Timothy, 2 Peter, Polycarp to the Philippians 1-12, 2 Clement, Gospel of the Nazoreans, Gospel of the Ebionites, Didache 1:3b-2:1, Gospel of Peter.

Crossan believes the Jesus tradition must be excavated to identify the layers at which material developed. His method is inventory (identifying texts in their historical situation), stratification (positioning texts in chronological sequence) and attestation (determining independence or interdependence of sources) (Crossan 1992:xxxi). 


\subsection{Difficulties with stratification}

For several reasons this stratification is not without difficulty.

Firstly, the boundaries are arbitrary. The first two stratae contain twenty years, the third forty, and the fourth thirty, implying "that a document written in 81 belongs with one written in 119 rather than one written in 79" (Wright 1996:49, n102). Q and Mark, or Mark and Luke, are closer than appears because Crossan puts them into separate stratae (Allison 1998:18). The divisions are artificially sharp and do not relate to history. The catastrophe of $70 \mathrm{CE}$ is a more likely break than Crossan's first break in $60 \mathrm{CE}$ (Allison 1998:16). Similarly, if the Caligula crisis in 40 generated the socalled "Little Apocalypse" (Moule 1966:117), it could have stimulated other documents. A break in 40 might mark the transition from collation of oral traditions to compilation of hortatory documents. Further breaks depend on how many boundaries can realistically be proposed. "Why not three, or five, or six?" (Allison 1998:14).

Secondly, precise dating of sources into stratae is difficult to establish. The Gospel of Thomas dates from "any time between the birth of the Jesus movement and the end of the 2nd C" (Kloppenborg 1990:88). Even if Q is a document (Wright 1996.48), Crossan's first stratum is mainly sayings-gospels, whose lack of controlling narrative framework allows the tradition to develop as a cumulative collection, raising the question of which form of the text should be dated (Kloppenborg 1990:89). Dating of sources significantly affects Crossan's stratae: if Q is 60s rather than 40s, one-third of his first stratum is now second stratum (Allison 1998:16). Accused of deliberately choosing the earliest dates for extra-canonical sources and the latest dates for intra-canonical sources, Crossan claims scholarly consensus (Crossan 1998:115). There is little consensus: Mark could be pre-war (Cranfield 1977:8) or post-war (Kümmel 1975:98). Luke may be early post-war (Marshall 1978:34f) or as late as 90 (Kümmel 1975:150f). Crossan appears to choose convenient parts of the consensus. "Paul, Mark, and Q are probably our earliest sources, and nothing non-canonical can be confidently placed before 70 CE" (Allison, 1998:17).

Thirdly, stratification indicates the date of a text, but not the provenance of the contents. "A unit from the fourth stratum could be more original than one from the first stratum" (Crossan 1992:xxxii). 
Early tradition could be preserved in a late document (such as Luke) because the source was reliable, while an earlier document (such as Mark) may preserve a less original version. Earlier forms of oral tradition are not superseded by later forms, but earlier tradition could be preserved in later documents (Dunn 2003a:336). Allison compares problems with Crossan's stratae with geological problems such as inverted stratae and thrust faults (Allison 1998:19).

By comparison, argues for an oral traditioning process like a series of performances, rather than layers. "An oral retelling of a tradition is not like a new literary edition" (Dunn 2003a:248). The default mindset of modern western culture has trapped scholarship into a literary paradigm, preventing scholars from recognising how differently oral cultures operate (Dunn 2003b:139).

Crossan's model is helpful, given the difficulties in establishing correct dates and stratae. It stresses the dating of a document, but overshadows the links between documents in different stratae. A better model would be the bands in a rainbow, or a family tree, illustrating links and influence across the stratae. Stratification is helpful, but is too firm to accommodate the more fluid relationship of oral tradition and documentary tradition suggested by Dunn.

\section{EXTRA-CANONICAL SOURCES}

Crossan has stratified many sources, from complete texts through manuscript fragments to hypothetical sources for which no document exists. We will concentrate on the major extra-canonical sources, and simply note in passing the existence of a number of papyrus fragments, too fragmentary to be of help (Theissen \& Merz 1998:51).

\subsection{The Logia source ' $Q$ '}

No documentary evidence exists for $\mathrm{Q}$. The term defines the material common to Matthew and Luke but not in Mark. A huge edifice stands on hypothetical foundations. Streeter proposed a missionary handbook containing an ethical supplement to the kerygma; Bultmann asserted an expansion from an Aramaic original into a Greek eschatological document (Kloppenborg 1990:18f); most define it as a sayings-gospel within the genre of sayings-collections like Proverbs, Pirke Aboth, and the Gospel of Thomas (Kloppenborg 1990:21). Robinson distinguishes it as a "discourses source" because the material is already in clusters, whereas Thomas has no apparent 
train of thought (Kloppenborg 1990:ix). The structure is thought to be better preserved in Luke. The different types of material may represent different redactional stages. There is no awareness of the events of 70; Theissen \& Merz sees links with the crisis of 39-40, and the Pharisees as persecutors suggests the 40's or early 50's (Theissen \& Merz 1998:29). It may originate from a "Q community" in Northern Galilee (Kloppenborg 1990:6).

The theology of Q depends on the redaction of different levels. One view, perhaps influenced by Thomas, posits an early Christian community picturing Jesus as a "teacher of aphoristic, quasiGnostic, quasi-Cynic wisdom" which "knows nothing of an apocalyptic future expectation, and is silent about 'the coming of the son of man': the End ... has come with the teaching of Jesus ... of a special and hidden wisdom which sets his hearers apart from the rest of the world" (Wright 1992:437). Later redaction added the apocalyptic parts of the document known by Matthew and Luke, transforming a sapiential collection into an apocalyptic text and realized eschatology into "a future orientated, much more Jewish, eschatology" (Wright 1992:438). Reconstruction of redactional stages is hypothetical, and conclusions based upon the final primarily eschatological redaction (Theissen \& Merz 1998:28). It begins with John the Baptist's eschatological preaching, continues with the beatitudes, and ends with parousia sayings. It was not simply a supplement to the kerygma, but proclaimed an independent understanding of Jesus' eschatological significance (Kloppenborg 1990:19).

It is argued that it can be explained by Luke's use of Matthew as a source (Goodacre 2002:vii), although this was rejected by Streeter (Streeter 1924:183). Even allowing the two-source hypothesis as the best solution of the synoptic problem, Q is less firm than apparent. "We know the Q Gospel itself for sure when Matthew and Luke agree exactly in their separate presentations of it - when, in other words, they fail to redact it at all. If one but not the other redacts it, or if both redact it differently, we lose any secure base text for comparison and cannot be sure what was in the $\mathrm{Q}$ Gospel and what was done to that gospel by either or both evangelists" (Crossan 1998:384). Further, if Matthew or Luke used Q material which the other did not, it would be impossible to know it was Q (Streeter 1924:185). If they treated the Q material the same way they did Mark, Q could have been twice as long as currently 
thought (Wolter 2004:117). Reconstructing Q and especially making firm evaluations of its theology becomes an increasingly tenuous exercise.

The supposed Q-material varies. The preaching of the Baptist (Mt 3:7-10= Lk 3:7-9) is virtually verbally identical (Huck 1963:1011), the faithful and wise servants (Mt 24:45-51 = Lk 12:42-46) less so (Huck 1963:178), and the talents (Mt 25:14-30 = Lk 19:12-27) very loosely paralleled (Huck 1963:179f). If Matthew and Luke worked from a manuscript, all parallels should be equally strong. The differences suggest a family of sources, documentary sources and "different cycles of oral tradition ... where verbal resemblance is small" (Streeter 1924:184).

A Q-community or movement is likely, since the handing on of tradition is a community function (Dunn 2003b:150). The community is not defined by the document, as if it had no other document and the document completely encompassed the community's theology. The assumption that the Q-community did not know or care about Jesus' death because there is no passion narrative is a significant argument from silence (Dunn 2003b:151). Jesus' death was known (Q 6:22-23; 13:34-35; 11:49-51; 14:27), and they may have had other documents containing passion-traditions.

There are further questions about redaction-history. Kloppenborg suggests a sapiential original, with eschatological texts in the second redactional layer (Kloppenborg 1990:22). He assumes that they belong to different periods. If the final redactor mixed genres, the primary redactor may have mixed them (Dunn 2003b:152). Schiavo argues contrary to Kloppenborg that $Q$ is a strongly eschatological document and that apocalyptic elements are at its core rather than later additions (Schiavo 2002:164). Material defined as secondary might be primary. Similarly, redaction demonstrates previously collected clusters with no unifying motif (Dunn 2003b:156f). The clusters (Sermon on the plain 6:20-23, 2749; teaching on discipleship and mission 9:57-62; 10:2-11, 16; teaching on prayer 11:2-4; 9-13; encouragement to fearless confession $12: 2-7$; 11-12; the right priorities $12: 22-31,33-34$; more teaching on discipleship $13: 24 ; 14: 26-27 ; 17: 33$; 14:34-35) may contain teaching from meetings of the communities. The collection need not have happened until final redaction into the document used by Matthew and Luke. Material brought in at the redactional stage 
could be older (Dunn 2003b:158). Apocalyptic sayings could be earlier tradition, rather than later community creations.

Rather than an alternative kerygma to that of the Pauline communities, Q represents a number of tributaries flowing into the mainstream, and is not as distinct as suggested.

\subsection{The Gospel of Thomas}

Before 1945, Thomas was only known through critical references in the Fathers (Theissen \& Merz 1998:37). It belongs to the literary genre of "sayings-gospel", containing 114 sayings, about half of which have synoptic parallels. The Nag Hammadi manuscript is 2nd $\mathrm{C}$, but initial composition could be any time from the "birth of the Jesus movement" via the decades of the canonical Gospels (Kloppenborg 1990:88) to late 2nd century Gnosticism (Gärtner 1961:271).

Final redaction is no more a clue to the age of the contents than in the canonical Gospels. The question is whether Thomas is dependent upon the canonicals or is independent Jesus-tradition. There are five instances of possible synoptic influence in Thomas (Kloppenborg 1990:86), meaning dependence on synoptic tradition, or scribal harmonisation. Only five possible dependences out of seventy parallels is no strong case for dependence.

Material developed according the theological trajectory of the community. Thomas 11:1-4 has Gnostic tendencies, including a speculative cosmology (Funk \& Hoover 1993:479) and the belief that Adam was androgynous, and the fall caused sexual differentiation until the restoration of non-sexual perfection (Kloppenborg 1990:98). Thomas 22:4-7 begins from a parallel to a canonical saying (Mk 10:14-15; Mt 18:3; 19:13-15; Lk 18:15-17). Comparison indicates both the possible original saying and its development into later Thomas-Christianity. By comparison, Thomas 9:1-5 (Funk \& Hoover 1993:478) and Thomas 65:1-7 (cf Mk 12:1-12; Mt 21:33-39; Lk 20:9-15a) contain versions of parables arguably more original than the canonical versions. Synoptic versions reveal continuing allegorical development (Theissen \& Merz 1998:39) is lacking in Thomas.

Thomas is very different from the canonical Gospels, and represents early Gnosticism (Theissen \& Merz 1998:40). If the sayings in Thomas are more original than the canonical versions, they represent an earlier stage in gospel development. They may 
indicate an alternative non-eschatological wisdom 'kerygma', which became Gnostic. However, the absence of future eschatology does not suggest that it was a later addition, but bedrock Jesus tradition excised from Thomas due to Gnostic theological motivation (Dunn 2003b:164f).

\subsubsection{Thomas and John}

Kloppenborg sees links with Johannine Christianity (Kloppenborg 1990:106f):

- $\quad$ Words are the source of life (Thom 1, see Jn 6:68; 8:51);

- Jesus is the redeemer who descends to earth, and has a special relationship with the Father (Thom 61:3, see Jn. 3:35; 13:3);

- John's discourses all begin from single sayings; Thomas might have preserved the originals (Kloppenborg 1990:109) Thomas 13:5, see John 4:14; 7:37-38; Thomas 24:1-3, see John 11:9-10; Thomas 92:1-2, see John 16:23-24; Thomas 38:1-2, see John 7:33-34; 8:21; 13:33.

According to some scholars, John's assumed dualism of light and dark, spirit and flesh, has affinities with Gnosticism and thus Thomas. John and Thomas might have shared sayings-traditions, or John might have known Thomas. Thomas the disciple features more in John's Gospel than elsewhere (Barrett 1978:393), but this may be coincidence (Kloppenborg 1990:90).

\subsubsection{Thomas and Paul}

Since Thomas is entirely composed of sayings, and Paul uses few sayings, there are only few connections. However, Paul spent fifteen years in Syria, where the sayings-tradition was at its strongest (Kloppenborg 1990:110). He must have been aware of their tradition. Some of his practices suggest influence:

- Thomas 53 believes that circumcision is useless. There is no parallel in the canonical sayings of Jesus but many in Paul (Rm 2:25-29; Phlp 3:3; 1 Cor 7:17-19; Gl 6:5). Ideas like "circumcision in spirit" may have come from the sayings tradition (Kloppenborg 1990:111), or later, from Gentile influence (Funk \& Hoover 1993:504).

- While the sayings tradition doesn't explicitly exclude women from leadership, Thomas 14 may address opposition to women's ministry by making them 'honorary males'. Paul's 
inclusion of women in his organisation may have been influenced by Thomas communities (Kloppenborg 1990:112).

Thomas may also illustrate why Paul eschewed the sapiential approach. Some of the Corinthian problems concerned claims of special wisdom $(4: 8 ; 6: 12 ; 10: 23)$. Paul used their own words against them (1 Cor 2:9-10a), similar to Thomas 17. His opponents may have anticipated the eschatological Kingdom (compare Thom 3; 113; 51). 1 Corinthians $4: 8 \mathrm{~b}$ may be an ironic response to a saying like Thomas 2:4. Paul's Corinthian opponents were not ThomasChristians (Wright 1996. 62f), but there are similarities. Thomas shows how the sayings tradition could produce views similar to Gnosticism. Paul was not ignorant of the sayings (Dunn 1998:185), but rejected a method based upon them because it led to unacceptable theology.

Thomas certainly illustrates aspects of the development of gospel tradition. To argue that it is earlier than the canonical gospels (Crossan 1992:427ff), is going further than the evidence will permit. The lack of resurrection tradition similarly does not signify ignorance of the stories, but could indicate either tacit acceptance or theological excision due to later Gnostic influence.

\subsection{The Didache}

The Didache is a community rule, comparable to Qumran (Crossan 1998:365; 396). It presents as instructions based on sayings of Jesus, for pagans intending conversion (Kleist 1948:3). It contains a development of the Two Ways treatise in the Epistle of Barnabas, and instructions for early Christian community (Staniforth, 1987: 188). Organisation is relatively primitive (see Eph. 4:11; 1 Cor 12:28); charismatic leaders are prominent (Did 11:3; especially 13:3) and the presbyterate is not distinct from bishops and deacons (1 Clement to the Corinthians distinguishes bishops, presbyters and deacons) (Kleist 1948:6). The finished document dates from the mid1st C to the 3rd C (Staniforth 1968:189).

There is no link between the Didache and Pauline or Johannine tradition, but connections with synoptic tradition. Opinions range from dependence on common sources, to dependence on Matthew and Luke, to total independence (other than Did. 1:3b-2:1, arguably a later insertion). Crossan placed Didache 1:1-3a, 2:12-16:2 in his Third Stratum (80-120 CE), and 1:3b-2:1 in the Fourth Stratum (120-150 CE) (Crossan 1991:433), but later identified problems: 
- $\quad$ it assumed a long-lasting written constitution and training programme with no Jesus tradition;

- $\quad$ it doesn't explain why editors chose only these sayings from Matthew and Luke, leaving eucharistic and apocalyptic material;

- $\quad$ the gospel texts were becoming normative, yet the insertions were freely edited;

- the sayings were never cited as sayings of Jesus (Crossan 1998:386f).

Comparison with $\mathrm{Q}$ suggests a mini-catechism, centred on a nonviolent interpretation of the Golden Rule (Lk 6:36; Mt 5:48), embedded in "a very traditional form of ethical catechesis known as the Two Ways - the ethical way of life versus the unethical way of death" (Crossan 1998:396). Crossan argues that this section of the Didache is early. He attempts to trace Jesus' sayings through the Common Sayings Tradition into Q and the Gospel of Thomas. The Didache "crosses the Q Gospel's trajectory at a very early stage certainly closer to its Common Sayings Tradition roots than to its finished apocalyptic consummation emphasizing the Son of Man" (Crossan 1998:407).

\subsection{The Common Sayings Source}

The Common Sayings Source arises from a comparison of Q, Thomas, and the Didache. It is "the corpus of material common to the Q Gospel and the Gospel of Thomas ... redacted quite divergently by each gospel according to its own particular theology" (Crossan 1998:254). Crossan's method, having defined Q as redactionally apocalyptic and Thomas as Gnostic, is to identify the characteristics of the original sayings. "The original sayings tradition contained neither Gnosticism nor apocalypticism, but required redactional adaptation toward either or both of these eschatologies" (Crossan 1998:255). The original character of the sayings tradition, and thus Jesus' teaching, is defined as sapiential.

This reconstruction is circular. Both redactional tendencies are assumed as unique to the document concerned, and different from Jesus' own approach. On the basis of Crossan's prior reconstruction of Jesus as an aphoristic teacher (Crossan 1992:422) apocalyptic material in the Jesus tradition is by definition later and redactional. If, however, Jesus did use apocalyptic eschatology (Sanders 
1993:182), apocalyptic material is not necessarily due to redaction. If a saying has two different redactions, one of which is apocalyptic, the original may have been non-apocalyptic, but it is equally possible that an apocalyptic original was changed. Jesus may have used apocalyptic eschatology, but certainly did not use Gnostic teaching. However, if Thomas-gnosticism found a sapiential source, wisdom sayings of Jesus may have been adaptable by a Gnostic redactor. Original Jesus sayings may have been either apocalyptic or sapiential, thus not so distinctive from the redactional tendencies of $\mathrm{Q}$ and Thomas. Crossan's method of discerning the Common Sayings Tradition should be treated cautiously.

Caution is necessary with such sources. While there is documentary evidence for the Gospel of Thomas, Q is no more than a hypothetical text. Reconstructing a hypothetical sayings source from a hypothetical sayings gospel is stretching credulity.

\subsection{The Gospel of Peter}

Peter was written after 70, but before the letter of Serapion in 190 (Theissen \& Merz 1998:49). Crossan places it in the Fourth Stratum (120-50 CE), as a composite of earlier traditions (Crossan 1992:433). These include the "Cross Gospel", from his First Stratum, argued to be the single source of all intra-canonical passion accounts (Crossan 1992:429). Crossan's reconstruction (Crossan 1992:465f) demonstrates commonality with the empty tomb narratives, but has nothing comparable to the upper room, Emmaus or Galilean appearances. It appears to be derivative. Dunn accepts that the Gospel of Peter may witness to earlier (oral) sources for the canonical Gospels, but dismisses "the so-called Cross Gospel" (Dunn 2003b:170). Meier rejects Crossan's method as selfcontradictory, as both the Gospel of Peter and the hypothetical Cross Gospel show dependence on the Synoptics (Meier 1991:117f). Craig considers Crossan's approach "idiosyncratic", and the Gospel of Peter "even if it contains some independent tradition (to be) a composition basically compiled from the canonical gospels" (Craig 1998:251). The Cross Gospel is an unfounded hypothesis, but if its existence is agreed, then the burial account meets Crossan's criterion of multiple attestation (Craig 1998:270).

\subsection{Jewish Christian Gospels}

Theissen \& Merz lists three (Theissen \& Merz 1998:51f) Jewish Christian Gospels: 
- $\quad$ The Gospel of the Nazarenes/Nazoreans is mid 2nd century, dependent upon Matthew, and composed in Aramaic or Syriac in Coele Syria. It contains legendary and novelistic developments, and emphasises ethical and social aspects beyond the synoptic tradition.

- The Gospel of the Ebionites is a revision of Matthew in Greek from Transjordan. Adaptations reveal Ebionite theology.

- The Gospel of the Hebrews has mythic-Gnostic tendencies. Theissen \& Merz dates it early in the second century (Theissen \& Merz 1998:53), whereas Crossan argues that it was composed independently in Egypt by the 50's (Crossan 1992:429). It is fragmentary, known mainly through patristic quotations.

Because of dependence at date these gospels do not change the landscape of the resurrection tradition.

\subsection{Summary of sources}

The New Testament is the main source for resurrection traditions. Other sources have varied relationships with canonical tradition. Most are later than canonical literature, with the exception of Q, which seems to be entirely contained within the synoptics. Many later documents are dependent upon canonical traditions. Some develop them, others diverge for theological reasons, especially Gnostic texts like the Gospel of Thomas. However, extra-canonical texts may contain early versions of canonical traditions, revealing earlier levels of Christian tradition which show how far later levels have moved from the original. However, what is thought typical of earlier tradition may be formed by later theological preferences. The issue is illustrated by the question whether the first Christians knew of the resurrection of Jesus.

\section{IMPLICATIONS FOR BELIEF IN THE RESURREC- TION}

The earliest traditions in $\mathrm{Q}$ and the extra-canonical documents contain nothing about Jesus' appearances or empty tomb. The significant exception is the hypothetical Cross-gospel. Q and Thomas are sayings-gospels with no narrative framework, and no Passion or Resurrection Narrative. There are no prediction-sayings, nor reference to a passion kerygma. Sayings-gospels imply Christian wisdom in which Jesus is present in his spoken words (Kloppenborg 
1990:25). Salvation comes through Jesus' words, rather than his death and resurrection. Crossan posits two early Jesus traditions, a sayings-based Life Tradition, and a passion-based Death Tradition (Crossan 1998:415). The sapiential Life Tradition is an alternative to the passion kerygma (Kloppenborg 1990:21), and knows nothing of death and resurrection. Crossan therefore argues that Resurrection traditions are later midrashic development. The Didache's eucharist tradition has no reference to the body and blood (Crossan 1998:434), suggesting a Common Meal Tradition alongside the Common Sayings Tradition in the earliest Christian tradition.

Against this, the passion traditions are among the best-attested in the New Testament. Jesus' execution and burial are deeply rooted in the tradition: the burial story is unadorned by theological or apologetic development (Bultmann 1963:274). It indicates historically early knowledge about Jesus' end. There must have been specific reasons for not including such clear knowledge, even as martyrdom, such as the possession of other documents containing early passion and resurrection tradition (Dunn 2003b:150). Sayingsgospels were not expected to contain everything. Q may not have been a supplement to the passion kerygma (Kloppenborg 1990:19), but may have been a companion volume. Elsewhere, there were theological reasons for exclusion. In Thomas, the Gnostic tendency would militate against resurrection sayings being preserved. They were known, but on theological and philosophical grounds thought irrelevant. Theologically-motivated excision would be very likely (Dunn 2003b:165).

The argument that the burial and resurrection traditions were later theological innovations, possibly midrashic (Spong 1995:229, 282 ) is unsafe. Firstly, it can be argued that the communities transmitting the sayings-gospels had access to other sources. Secondly, some of the earliest material contains appearance stories, and arguably reference to the empty tomb (1 Cor. 15:4). Such early tradition suggests a basis in history.

\section{CONCLUSIONS}

A survey of sources reveals the complex roots of tradition and texts. Despite contrary arguments, the extra-canonical texts do not significantly alter the landscape. The New Testament texts are still the best sources for the resurrection. Where no resurrection traditions exist (eg Thomas) that may be for reasons of theology (eg a 
Gnosticizing tendency leading to excision) or tacit acceptance (namely that the community has resurrection stories elsewhere). Where there is extra-canonical resurrection material (eg. the socalled Cross Gospel) it can be shown to be dependent on canonical tradition. The majority of scholars prefer canonical to non-canonical sources for Jesus tradition, and even Crossan, who apparently prefers non-canonical sources, ends up with a surprisingly synoptic Jesus (Willitts 2005:98).

\section{Consulted literature}

Allison, D 1998. Jesus of Nazareth - Millenarian Prophet. Minneapolis: Fortress Press.

Barrett, C K 1978. The Gospel According to St John (2nd ed). London: SPCK.

Bultmann, R 1963. The History of the Synoptic Tradition. Oxford: Blackwell.

Craig, W L 1998. John Dominic Crossan on the Resurrection of Jesus, in Davis, Kendall and O'Collins (eds.). The Resurrection. Oxford: University Press).

Crossan, J D 1992. The Historical Jesus: The Life of a Jewish Peasant. San Francisco: Harper San Francisco.

-, 1998. The Birth of Christianity. San Francisco: Harper San Francisco.

Dunn, J D G 1998. The Theology of Paul the Apostle. Edinburgh: T \& T Clark.

-, 2003a. Jesus Remembered. Grand Rapids: Eerdmans.

-, 2003b. Altering the default setting: re-envisaging the early transmissions of the Jesus tradition. New Testament Studies 49(2), 139-175.

Funk, R W \& Hoover, R W 1993. The Five Gospels. San Francisco: Harper Collins.

Gärtner, B 1961. The Theology of the Gospel of Thomas. London: Collins.

Goodacre, M 2002. The Case Against Q: studies in Markan priority and the Synoptic problem. Harrisburg: Trinity Press International.

Huck, A 1963. Synopsis of the First Three Gospels. Oxford: Blackwell.

Kleist, J A 1948. Ancient Christian Writings - the Works of the Fathers in translation. New York: Paulist Press

Kloppenborg, J 1990. Q Thomas Reader. California: Polebridge Press.

Kümmel, W G 1975. Introduction to the New Testament. London: SCM.

Marshall, I H 1978. The Gospel of Luke. Exeter: Paternoster Press.

Meier, J P 1991. A Marginal Jew: Re-thinking the Historical Jesus. New York: Doubleday.

Moule, C F D 1966. The Birth of the New Testament (2nd ed). London: A \& C Black.

Sanders, E P 1993. The Historical Figure of Jesus. London: Penguin Books.

Schiavo, L 2002. The Temptation of Jesus: The Eschatological Battle and the New Ethic of the First Followers of Jesus in Q. Journal for the Study of the New Testament. Volume 25(2), 141-165.

Staniforth, M 1987. Early Christian Writings (revised). London: Penguin. 
Streeter, B H 1924. The Four Gospels: A Study of Origins. London: Macmillan. Theissen, G \& Merz, A 1998. The Historical Jesus. London: SCM.

Willitts, J 2005. Presupposition and Procedures in the Study of the 'Historical Jesus': Or, Why I Decided Not to be a 'Historical Jesus' Scholar. Journal for the Study of the Historical Jesus (5.1).

Wolter, M 2004. Reconstructing Q? Expository Times. 115(4), 115-119.

Wright, N T 1992. The New Testament and the People of God. London: SPCK.

-, 1996. Jesus and the Victory of God. London: SPCK. 